\title{
Islamic Peace Education: Internalization of God's Feminine Names to Santri in the Syukrillah Islamic Boarding School
}

\author{
R. Widya Setiabudi Sumadinata, Otong Sulaeman, Dina Yulianti \\ Padjadjaran University, Bandung, Indonesia \\ Sadra Islamic College, Jakarta, Indonesia \\ Padjadjaran University, Bandung, Indonesia \\ w.setiabudi@unpad.ac.id, osleman@yahoo.com,dina14@unpad.ac.id
}

\begin{abstract}
Amid public concern about increasing radicalism and intolerance among Indonesian students, discussions on the importance of peaceful education came again to draw attention. Through a qualitative research, we found a method of peaceful education teaching that is intrinsic and based on local wisdom about the feminine attributes of God which can be internalized by students so that they have a culture of peace. Through this method, the Syukrillah Islamic Boarding School, Cipongkor, West Java, has taught a comprehensive understanding of religion, recognition of different opinions on religions, and feminine characteristics which are essential qualities desired in peaceful education. This article offers a new perspective of peaceful education by adopting a local wisdom concept that bopefully enriches the discussion of peaceful education.
\end{abstract}

Keywords: peaceful education, tashawwuf, feminine attributes of God

\begin{abstract}
Abstrak
Di tengah kekhawatiran publik tentang meningkatnya radikalisme dan intoleransi di kalangan pelajar Indonesia, diskusi tentang pentingnya pendidikan damai kembali mendapatkan perbatian. Melalui penelitian dengan metode kualitatif, penulis menemukan metode pengajaran pendidikan damai yang intrinsik dan didasarkan pada kearifan lokal tentang sifat feminin Allab yang dapat diinternalisasi oleh siswa sehingga mereka memiliki budaya damai. Melalui metode ini, Pondok Pesantren Syukrillah, Cipongkor, Jawa Barat, telah mengajarkan pemahaman yang komprehensif tentang agama, pengakuan terbadap keberagaman pendapat dalam agama, dan karakteristik feminin yang merupakan kualitas penting yang diinginkan dalam pendidikan perdamaian. Artikel ini menawarkan perspektif baru pendidikan perdamaian dengan mengadopsi konsep kearifan lokal yang diharapkan dapat memperkaya diskusi tentang pendidikan perdamaian.
\end{abstract}

Kata kunci: pendidikan perdamaian, tashawwuf, sifat jamaliah Allah

Permalink/DOI: https://doi.org/10.18326/infs13.v14i1.49-70 


\section{Introduction}

The acts of terrorism that have occurred in the last few years in various parts of the world, including Indonesia, and the rise of intolerance attitudes in this country have raised concerns among academics and thinkers. Several surveys conducted in Indonesia over the past few years (LIPI 2010; FISIP UIN Syarif Hidayatullah Jakarta, 2011; Setara Institute 2015, Wahid Institute 2016, and Alvara, 2017) showed an increase in radicalism and intolerant attitudes among students and universities. Even more interesting, they tend to be more intolerant of different ideas or groups within the internal Muslim community than those who adhere to other religions (Syafruddin and Ropi, 2018). This phenomenon has brought back discussions about the importance of Peace Education.

UNICEF in 1998 stated that peace education is a mechanism of fostering the awareness, skills, attitudes and values required to bring about changes in behaviors that will allow children, youth and adults to avoid open and systemic conflicts and violence; to resolve conflicts peacefully; and to develop a peaceful atmosphere, both intra-personally and interpersonally on a national or international level (Fountain, 1999). Meanwhile according to UNESCO (2008:3), peace education is:

Education for non-violence and peace includes training, skills and information directed towards cultivating a culture of peace based on human rights principles. This education not only pro-vides knowledge about a culture of peace, but also imparts the skills and attitudes necessary to defuse and recognize potential conflicts, and those needed to actively promote and establish a culture of peace and non-violence.

The most prominent thinker in Peace Studies, Johan Galtung, in exploring the concept of peace, distinguishes between negative peace and positive peace. Negative peace means the absence of violence and sometimes achieved through non-peaceful ways. On the other hand positive peace is achieved by social integration and peaceful ways (Galtung, 2011). Galtung in his speech at the European Commission (2009) stated that the creation of peace requires the qualities possessed by women, including holisticism, 
empathy, nonviolence, promoting dialogues and discussions, and compassion. In fact, according to Galtung, the fundamental nature of women is leaning towards 'peace' which is interpreted as " $a$ situation where conflicts are transformed equitably and projects of equitable cooperation are built; a relation between parties".

As stated by the Former Under-Secretary-General and High Representative of the UN, Ambassador Anwarul K. Chowdhury, it is necessary to enrich material in peace education by exploring spiritual and cultural values in local communities (Navarro-Castro and Nario-Galace, 2010, p. xiii). Setiadi et al. (2017) explained that peace education develops a peaceful thought in the mind of humans, namely to bring peace of mind in the heart, then peace in interacting with others and their environment. Since humans are generally bound by tradition and culture, it is essential to instill the values of peace based on local wisdom.

The values of peace as local wisdom certainly do not appear immediately, but proceed so long that eventually proved to contain a favor for life. In this case, local knowledge in a tradition and culture is strongly attached to people's lives. That is, to a certain extent there are perennial values that are deeply rooted in every aspect of cultural locality.... the essence of education itself as a learning process that is based on the formulation of philosophical values that every individual is able to understand the values of truth and universal truth. Through education, each person must not only be good for itself, but should benefit the wider society and be able to establish a good relationship with God the Creator.

There are two key phrases from Setiadi's explanation which the author underlines, namely that peace education must involve perennial values that are rooted in local culture and establish good relations with God. In this research, we explore more in-depth the concept of peaceful education based on Islamic values, especially values that related to tashawwuf. According to Shaykh Muhammad Amin al-Kurdi, Sufism is a science that explains the states of the soul (nafs), so human will have the ability to distinguish the good and bad things of the soul, how to cleanse it of the bad (traits) and fill 
them with praiseworthy qualities, how to perform suluk, the path to Allah, and leave (prohibitions) of Allah towards (commandments) Allah SWT. Sufism contains four elements, namely metaphysics (things outside the natural world), ethics, aspects related to the soul, and aesthetics, namely the science of beauty and art (Badrudin, 2015: 1-3).

Some previous studies focusing on peace education in Indonesia, especially related to Islamic education, generally emphasize that Islam is a peaceful religion and it always calls for peace. On the basis of these assumptions, Hendry AR (2011) suggested a strategy to translate the content of peace into religious education materials, including mainstreaming the issue of peaceful education and promoting peaceful education literacy among Islamic educators. Sukendar (2011) examined the educational process in Latansa Islamic Boarding School, Demak, Central Java, and found that the teaching process there was very much in line with Peace Education, which includes diversity management, gender justice, emotional management although it does not specifically teach Peace Education. Nurcholish (2018) presents a number of Peace Education concepts that can be applied in the Islamic education curriculum.

Some researchers have conducted research around peace education in Islamic educational institutions. Hidayat, Sujana, Al Gadri (2018) researched through surveys and interviews conducted to obtain local conceptions of peace and other related aspects and finding that the pesantren community interpreted the word peace as correlated with solidarity, order, prosperity, and unity. Afifuddin (2017), in his research, concluded that the formation of Islamic character in Islamic educational institutions is very effective when delivered with a sufistic approach.

Meanwhile, related to the use of local wisdom in peace education, among others, Hidayah et al. (2017) recommended the Piil Pasenggiri, a local wisdom from Lampung which mean self esteem dan reponsible to the community, and mutual cooperation (gotong royong). Ratu, Misnah, Amirullah (2019) endorsed a Kaili ethnic concept "Nosarara Nosabatutu" (we are all brothers). dan Supriyanto, Saputra, Astuti (2019) recommended the using of 
"wayang" (performance of Javanese puppet) in educating peace. However, there has not been any discussion regarding how Sufistic teaching practices are utilized in educating peace in Indonesian school or pesantren.

In general, there are three levels of concerns of Peace Education: Peace Education as an effort to prevent wars; Peace Education as a form of education for various aspects that encourage peace, ranging from developmental education to human rights education; and Peace Education as education at personal level, that is to internalize the values of peace in a person (Page, 2010, 850). In this article, the author will explain how the Islamic Boarding School (Pesantren) Syukrillah seeks to internalize the values of peace in its students (santri) using the local wisdom method, namely, reciting the feminine name of God.

\section{Method}

This research is a qualitative study. As stated by Creswell (2013), in the qualitative study, the researchers gather data themselves to review documents, track actions, or interview informants and then analyze all data, make sense of it and organize it into categories or themes that cut through all data sources.

The authors conducted the research by visiting Cipongkor Village, Bandung Barat District, West Java Province, in April 2019. The authors interviewed the principal and teacher of Syukrillah Islamic Boarding School about the school the school's efforts to prevent radicalism and to teach peace education. The authors also elaborated what their reasons for teaching the concept of peace to students through reciting the names of God are. We then analyzed data from informants using a variety of literature studies, such as textbooks, documents, and journal articles.

\section{Literature Review}

Peace is often interpreted as the absence of a direct war of violence. Since the 1960s, Johan Galtung has offered a deeper understanding of peace by dividing peace into two types, namely negative peace and positive peace. This thinking is based on the fact that violence does not only appear in the form of war, terrorism, or riots that 
cause injury or death, but also in the form of poverty, hunger, and discrimination; all of which are rooted in social injustice. Negative peace is the absence of war and violence. On the other hand, positive peace is a condition when social justice is realized.

Galtung (2011) wrote that there are three categories of violence, namely direct violence, structural violence, and cultural violence. Negative peace in the case of direct violence is related to the absence of the violence itself by establishing a ceasefire. On the contrary, positive peace in this case is the presence of cooperation. In the structural violence (such as poverty, hunger, or social injustice), positive peace will arise in the presence of equity and equality and negative peace means the absence of exploitation. Galtung interpreted cultural violence as all forms of culture used to justify structural violence, including religion and ideology. Thus, in the cultural violence, positive peace will emerge in the presence of a culture of peace and dialogue. Oppositely, negative peace means no justification or no culture (Galtung, 2011 : 1-2).

In this article, we examine religious intolerance to find the way to overcome it. Based on the thoughts of Galtung and other PE thinkers, Navarro-Castro and Nario-Galace (2010:21) propose 5 levels of peace as illustrated in the following diagram. 


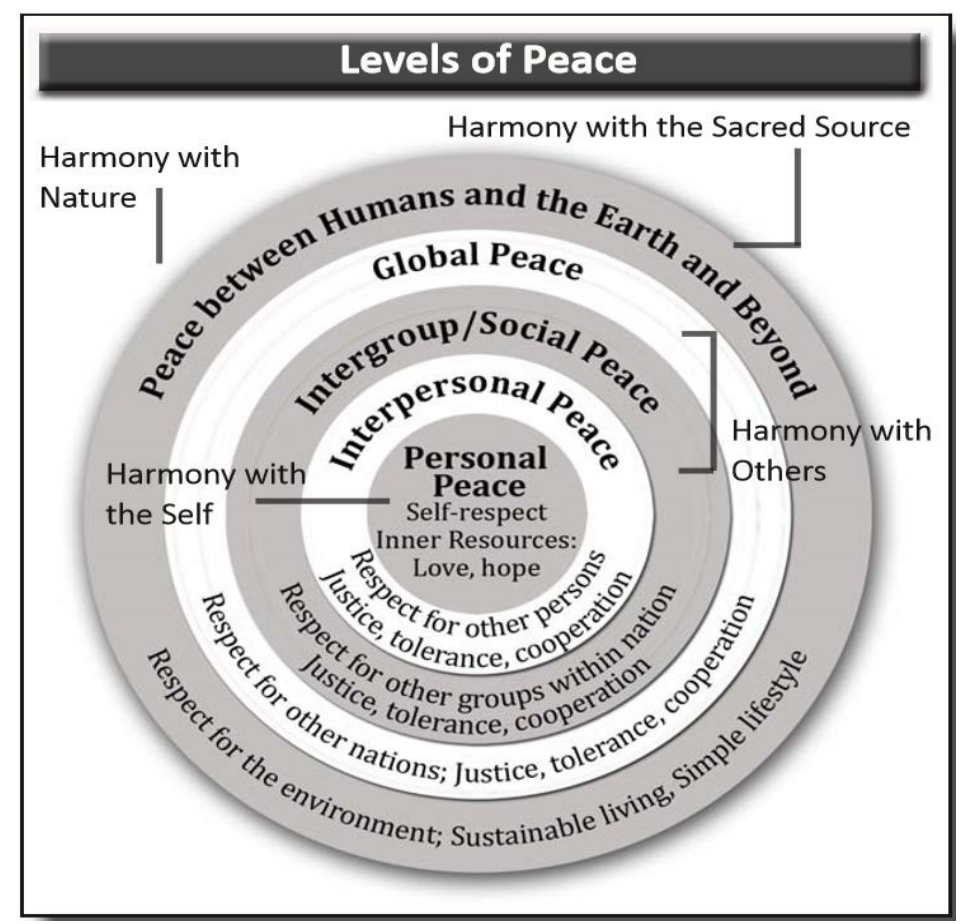

Source of diagram: Navarro-Castro and Nario-Galace (2010)

As the diagram shows, personal peace is fostering harmony and peace within oneself by creating self-respect, inner resources, love, and hope. When personal peace is achieved, it will increase to the next level of peace, which is interpersonal peace, where one is able to respect others and to uphold justice, tolerance, and cooperation. In the next level, a person is able to respect other ethnic groups, uphold justice, tolerance, and cooperation within the scope of one country and globally. The highest level is peace between humans and the environment (universe). Thus, it can be concluded that building the concept of peace at the personal level is the first step in Peace Education. In this article, the discussion will be focused on peace education at personal level.

Peace education at personal level (intrapersonal) is explained by Pilisuk (2011) and Carter (2010) as an effort to train students to manage their emotions, understand self-awareness, identify selfneeds, listen to inner voice, and realize their personal responsibility. 
How to implement these qualities in the teaching curriculum at school? Carter (2010) cites the objective of peace education curriculum in the US: to achieve the following competencies, namely knowledge, pluralistic acceptance, ethno relativism, self-management, peaceful discourse, proactive involvement, restoration, stewardship, and envisioning.

In 2009, Galtung conveyed a very important statement to be highlighted, that femininity, such as holisticism, empathy, nonviolence, promoting dialogue and discussion, and compassion were needed in creating peace. In Islamic spiritual studies, the terms "feminine nature" of God (jamaliab) and masculine nature (jalaliab) have been recognized (Subhani, 2003). Therefore, internalizing the feminine characteristics of God is highly correlated with feminine qualities needed in peace education. This brings us to the question, how should Islamic education institution teach this concept?

Al-Qaradhawi (1996:59-67) wrote that the main factor in the emergence of radical attitudes is the superficial and partial understanding of Islam. He stated that to obtain a comprehensive and deep understanding of religion, a learner should undergo a gradual learning process, not in an instant way. The learning process must be done from the most basic things, then ascends to higher religious concepts.

The gradually learning process is called taraqqi which is in harmony with the taraqqi concept known in the Sufism tradition. A sufistic journey is the process of human ascension toward God (taraqqi) and the decline (tanazzul) of God approaching His servants (Azra, 2005: 300). Therefore, the teaching of tasawwuf is believed to be quite effective in overcoming radical ideology. Tasawwuf is interpreted as an attempt by humans to adorn themselves with the attributes of God (al-takhalluq bi akblaqillah), especially feminine traits (jamaliab). Through tawawwuf, the attributes of God that were previously still in the form of potential in human beings will turn into actual ('Arabi, 1981: 266). Thus, humans will have good qualities in themselves. Intolerance is also another causal factor of radicalism. For this reason, efforts are needed to spread the concept of tolerance (tasamub) in religion to counter radicalism (Rodin, 
2016).

Peace According to Islamic Teachings

Islam is a religion that creates the concept of peace as the primary teaching. It is closely related to the root of the word Islam itself aslama-yuslimu with several semantic meanings: agree and obey, submit, surrender, follow, fulfil, convey, enter into peace, safety, or purity (dakhala fi al-salm au al-silm aw al-sal $\square m$ ). Of the other terms that are said to be the same, "Islam" is associated with the meaning of salvation, peace, and purity (Syalabi, 1985:28).

The principle of peace in Islam is not merely a slogan. It has become an inseparable part of other major Islamic teachings. The following are five principles in Islamic teachings which have a very close association with the concept of peace and coexistence.

(1) Attention to Common Values

Since its emergence, Islam is a belief presented the slogan of coexistence for all inhabitants of the world, all religions and nationalities. Al Qur'an tells the Ablulkitab,

Say, "O People of the Scripture, come to a word that is equitable between us and you - that we will not worship except Allah and not associate anything with Him and not take one another as lords instead of Allah." But if they turn away, then say, "Bear witness that we are Muslims [submitting to Him]." (Al Qur'an surah Ali Imran: 64)

This verse, according to Shirazi, shows that Islam invites the followers of other religions to acknowledge many points of likeness as a basis for peaceful coexistence, even though there are essential differences in terms of belief. This verse invites the religious adherents who believe in the teachings of their books (Ablulkitab) in which bear some resemblance to the teachings of Islam to find the common values to live together peacefully. This principle can be extended to cases when Muslims live side by side with followers of other religions (Shirazi, 1995:450).

(2) Disclaim Racism

Al Qur'an denounces all kinds of racism thoughts. It views that all human beings are children of one mother and father and thus 
expells the superiority of race, people and religion. Alquran, in its universal message, rejects racism. It exclaims,

"O mankind, indeed We have created you from male and female and made you peoples and tribes that you may know one another. Indeed, the most noble of you in the sight of Allah is the most righteous of you. Indeed, Allah is Knowing and Acquainted." (Al Qur'an surab Al-Hujurat: 13)

A critical principle of peaceful coexistence is the equality of human, not racism. Racism is a doctrine that sees all members of each race possess characteristics or abilities to distinguish it as inferior or superior to another race. It encourages its members to insult other races which will cause various problems for humankind. Based on the above verse, Qara'ati states that skin colour, race, and nationality differences should not cause one's virtue over others. In the view of the Qur'an, differences in language and skin colour are one of the signs of God's greatness. This difference is a way to get to know one another (Qara'ati, 1995:196-197).

Syabana stated these calls and expressions show that humanity is perceived to have the same meaning among the inhabitants of the universe. People from any region do not feel different from others in terms of humanity. Humans throughout history differ from one another in terms of language, skin colour, race and nation. However, Islam perceives all human are the sons and daughters of one father and mother (Adam and Eve), and all the differences that exist should not harm the humanity (Syabana, 2003: 542-543)

\section{(3) Paying Attention to Minority Rights}

Islam emphasizes the importance of peace by paying attention to the rights of minority groups. Islam sees that the existence of minorities in a society's structure is an inseparable part of sunnatullah. There is always be a small group of people who is different from the majority of people in a community. These differences can be related to race, ethnicity, culture, language, and also religious beliefs. Regarding this matter, Subhani (1990) stated that no religion guarantees freedom and preserves the glory and rights of minorities like in Islamic teachings. The teachings of Islam commanded its followers to do good deeds and be fair to adherents 
of other religions.

"Allah does not forbid you from those who do not fight you because of religion and do not expel you from your bomes from being righteous toward them and acting justly toward them. Indeed, Allah loves those who act justly." (Al Qur'an surah Al-Mumtahanah: 8)

In another verse, $\mathrm{Al}$ Qur'an states, "Allah only forbids you from those who fight you because of religion and expel you from your bomes and aid in your expulsion - [forbids] that you make allies of them. And whoever makes allies of them, then it is those who are the wrongdoers." (Al Qur'an surab Al-Mumtahanah:9)

According to Subhani, this verses permitted minorities and the ones who did not accept the Islamic teachings to live in an Islamic society and obtain rights as citizens if they do not cause disturbances to Islam and Muslims, nor showed hostility (Subhani, 1990: 526-530).

\section{(4) Helping Each Other in Kindness}

A critical pillar of social life is the culture of cooperation and mutual assistance among members of the community, in various fields of life. Without a culture of cooperation and mutual assistance, there will no be any social life. Social life is a space full of peace, and it requires cooperation and mutual assistance.

However, cooperation as a means for social life is not just any cooperation. Cooperation could mean conspiracy carried out by people who agree to do bad things and eliminate cohesiveness among members of a community. If people cooperate to create hostility and crime, then such cooperation and agreement endanger social life, and in turn, jeopardizes peace itself.

For this reason, the Qur'an emphasizes cooperation and mutual assistance in the sphere of goodness and piety and forbids cooperation in acts of sin and hostility.

"And cooperate in righteousness and piety, but do not cooperate in sin and aggression. And fear Allah ; indeed, Allah is severe in penalty." (Al Qur'an surah Al-Maidah :2) 
According to Zanjani (2000: 441-461), goodness and piety include justice, equality, peace and security; whereas sin and enmity include hegemony, exploitation, racism, and aggression which will only lead to destruction, violation and tyranny. The principles of cooperation and mutual assistance as contained in the verses of the Al Qur'an above show that Islam is very concerned about peace and peaceful coexistence among humans.

\section{(5) Justice Perspectives in Conflict Resolution}

Internal conflict is a natural thing for society. Triggers of conflict can be differences in scientific levels, maturity, conflicts of interest, social strata, and also the presence of people who have evil characters such as jealousy or arrogance. These triggers can create simple to very violent conflicts which endanger the integrity of society. If massive conflicts can uproot peace in society, Islamic teachings, which are very concerned about various possibilities that can undermine peace, has proposed a resolution in anticipation.

Al Qur'an states:

"And if two factions among the believers should fight, then make settlement between the two. But if one of them oppresses the other, then fight against the one that oppresses until it returns to the ordinance of Allah. And if it returns, then make settlement between them in justice and act justly. Indeed, Allah loves those who act justly." (surah Al-Hujurat: 9)

This verse contains two main concepts, namely peace and justice. Qara'ati stated, the disputes that arose between the believers (mukminin) were temporary, and therefore there was always an opportunity to reconcile disputed Muslims. However, there may be parties who are reluctant to make peace. So, Al Qur'an recommended being firm with this group. It could be that, for the sake of maintaining a sense of peace among the community, we must fight the dissident group. To fight the dissidents, we must use one principle as a parameter, namely justice. Without justice, the enforcement of peace is vague and certainly cannot last long (Qara'ati, 1995:176-178). 


\section{Result and Discussion}

Syukrillah Islamic boarding school is located in Bojongkoneng area of Sirnagalih Village, Cipongkor, Bandung Barat District, West Java Province. The school was founded in 1982 and currently led by Kyai Ceng Abdul Khaliq who is also a prominent ulama (religious leader) of Nahdlatul Ulama Organization. Currently, it has 100 students. We cross checked the information with another kyai nearby, Kyai Cecep Suryana, the chairman of Al-Ghuroba Islamic boarding school of Sindangkerta Village.

From this study, the researchers found that in the concept of teaching and learning applied at Syukrillah Islamic Boarding School, there are three important principles, as follows:

(1) The principle of taraqqi or bottom up, which makes the religious learning process of a santri (student) run gradually, not instantly. Through this principle, a student cannot study religion sporadically, without understanding the methods and principles of legal conclusions in religion.

Previous research showed that one of the causes of the emergence of radicalism in terrorists is their way of learning religion which does not follow the methods formulated by previous scholars. Only knowing few verses of the Al Qur'an and their history, they consider themselves to have mastered the religious sciences. So, their religious understanding is actually very partial and far from comprehensive level (Qaradhawi, 1996: 59-67).

The method of taraqqi prevents the emergence of such shallow and partial religious understanding. This method will encourage students to have a comprehensive understanding of religion, so that it is reflected in the peaceful and anti-radicalism Islamic religious buildings.

(2) The principle of tasamub or tolerance in respecting the religious opinions of other parties. In Syukrillah Islamic Boarding School, students were introduced to a variety of different religious opinions, leading to various religious ways. This model encourages santri to be tolerant. Tolerance is one of the important pillars of peace education, and conversely, intolerant attitudes are one of the 
main characteristics of radicalism.

The concept of tasamub aligns with Galtung's positive peace concept, "the presence of cooperative and harmonious relationships" (Page, 2010). In other words, peace does not always mean the absence of conflicts, but how to deal with conflicts and differences wisely in peaceful ways, not through violence.

(3) The principle of tashawwuf which emphasizes the importance of purification of the soul by decorating each person with the attributes of God, especially those of a feminine nature, such as loving, loving, gentle, generous, sharing sustenance, protection, etc. ('Arabi, 1981). The attributes of God are divided into two categories: masculine (jalaliah) and feminine (jamaliah) (Subhani, 1998). The students are taught that God is not just the Almighty, the Willing, and various other 'masculine' characteristics.

The third principle is also in line with the second principle (tasamub) which has a nuance of tenderness, accepting differences with an open heart.

Our informant explained that tashawwuf(Sufism) taught in the Syukrillah Islamic Boarding School was based on the teachings of Ibn 'Arabi which stated that tashawwuf means human efforts to decorate himself with the attributes of God (al-takhalluq bi akblaaqillah). This concept states that the names of Allah actually exist in humans. However, the existence of the names is still potential. Through the path of tashawwuf, the attributes of Allah manifest in human being ('Arabi, 1981). Our informants further explained that the attributes of God that should be imitated by humans through the path of tashawwuf are characteristics that belong to the jamaliab nature, also known as the feminine nature of God.

Muslim theologians claim that the attributes of God are divided into two broad categories: the nature of the salbi and the nature of tsubuti. The characteristics of the salbi are those whose names are accompanied by negation. For example, God is called Al Ghaib which means 'the Substance of the Unrepresented by the Five Senses', Al Akbar (the Unparalleled Greatness), Al Azhiim (the Unimaginable Glory, $A l A l y$ (the Most Unreachable Altitude), or $A l$ 
Maalik (the Supreme Indisputable of His Commandments). Because the characteristics of the Salbi show the immeasurable strength of God, the character of the Salbi is also called jalaliah (masculine character) ('Arabi, 1981).

Meanwhile, the character of the Tsubuti is the dimension of the names of God connoting soft and beautiful, such as the Most Gracious (ar-Rabmaan), the Most Merciful (ar-Rabiim), the Most Generous (al-Kariim), the Most Gentle (al-Latif), the Most Forgiver (at-Tawwab, al-Afuww), the Most Tolerant (al-Jami'), the Most Caregiver (al-Hafidz), the Omniscient (al-Aalim) or the Most Peacegiver (As-Salaam) ('Arabi, 1981).

What is taught by Sufism to be imitated by humans is the feminine attributes of God. Ibn 'Arabi stated that the nature of the jamaliah of God is known from the relationship between God and the cosmos. Such qualities emphasize submission to the wishes and desires of others, tenderness, and sensitivity ('Arabi, 1981).

Thus, according to Ibn Arabi, when God is seen and approached from His relationship with the cosmos, His feminine characteristics emerge (Murata, 1996). Then, when it is said that God's feminine traits can be imitated and internalized, this shows that humans are expected to imitate God's attributes in the context of their interactions with fellow human beings and the natural environment.

Every day, the students of Syukrillah Islamic Boarding School are required to recite and memorize these names of God (wirid) so that the names are internalized within themselves. The internalization of al-'Aalim (the Omniscient) encourages the students to increase their knowledge and insight into things in their surrounding and in the world. The characters of ar-Rahmaan, ar-Rahiim, al-Karim, alLatif (gracious, full of mercy toward others, generous, and gentle) are the characters of personal peace.

Internalizing the characteristics of the Most Forgiver (atTawwab, al-Afuww) and the Most Tolerant (al-Jaami') encourages the students to be tolerant and pluralist. They will easily accommodate and adapt when interacting with different cultural norms. As discussed above, the existence of minorities in a community structure 
is an inseparable part of a sunnatullah. There is always a minority group in every community. The people who are not ready for the existence of a minority group will experience social disintegration problems which in the end is the destruction of peaceful lives in these communities.

The students at the Syukrillah Islamic Boarding School are part of the Islamic ummah, a religion that is embraced by the majority of the Indonesian people. They will find in society people of different faiths and of different ethnicities, whose numbers are smaller. As we wrote above, various acts of radicalism that occurred in Indonesia made minority groups as objects. The radicalized people see themselves as part of the majority religion, which is superior to other religions in Indonesia. Strengthening tolerance, which is still doing good and being fair to minority groups with different religious beliefs, is a challenge faced by Indonesian Muslim. One of the ways taken at the institute is by encouraging students to internalize the nature of Allah Al-Jaami.

By internalizing Al-Jaami' into himself, the Syukrillah students would allow minorities who did not accept the teachings of Islam to remain alive in Islamic societies and obtain rights as citizens, provided they did not cause disruption to Islam and Muslims, also does not show hostility. This view is an implementation of the teachings of Islam, as stated in surah Al-Mumtahanah verse 8 and verse 9, which we have discussed above.

Internalizing the nature of Allah Al-Jaami' will also encourage students to be humble while avoiding racial arrogance, even religious arrogance. As discussed above, one of the crucial principles of peace and peaceful coexistence is the principle of equality and equality. The students are expected to stay away from feeling superior based on class and nation, or being racist. It is hoped that the students have a humble attitude in dealing with the plurality in their lives and see other people's piety only to be judged by God. This attitude is following the principle of glory based on piety, as stated in surah Al-Hujuraat verse 13 .

They will also have the ability to manage their self-awareness to remain stable when facing conflicts. This mindset is also a 
favourable implication of the internalization of the nature of Allah Al Jaami' because the ability to control consciousness in order to find points of similarity rather than thicken the differences is only possible by people who have a tolerant culture.

The internalization of the Most Peacegiver (As-Salaam) character will encourage the students to be involved in the peace discourse. Everything will be seen from the side of peace, and all conflicts will be seen from the perspective of how to reconcile the conflicts.

The internalization of the nature the Most Caregiver (alHaafidz) encourages the students to be responsible of their social environment. The peace activists need the character of caregiver to solve the social and environmental problems. The culture of cooperation and mutual assistance among community members is one of the pillars of social life. However, the expected cooperation is not a collaboration that aims badly and results in the elimination of cohesiveness among members of the community. Islam teaches cooperation and mutual assistance in the sphere of goodness and piety, not in acts of sin and enmity. Thus, good Muslims will always be involved in community activities to live the principles of cooperation and help one another in goodness and piety.

The students at the Syukrillah Islamic Boarding School will one day be in the midst of the community. Islamic boarding schools teach them that one day they can lead a social life in the right way. One necessary provision that must be owned by a community to be able to work together is the attitude of responsibility.

One of the implications of internalizing the nature of Allah Al-Haafidz is the emergence of Muslims who have a sense of responsibility. People who have social responsibility will engage in various community activities and revive a culture of mutual assistance in goodness and piety.

Internalizing the nature of Allah Al-Haafidz also encourages students to have a sense of responsibility to reconcile the conflicting parties. Ideally, society must free from conflict. However, the facts show that differences in interests and character quality among 
community members often trigger conflict. Thus, a Muslim must always prepare himself to face the potential conflict that arises in his community.

When there are conflicts that arise in his/her society, a person who has a sense of responsibility will undoubtedly appear and try to reconcile the parties to the conflict. Of course, good Muslims must understand and hold fast to several essential principles in order to resolve the conflict, including the application of the principle of justice in each phase of conflict resolution.

It can be concluded that all the feminine characteristics taught to students at Syukrillah Islamic boarding school are very much in accordance with the desired competency material in the peace education curriculum cited by Carter (2010) as summarized in the table below.

Table 1.

Competency material in the peace education of Syukrillah Boarding School

\begin{tabular}{ll}
\hline The feminine qualities & Competencies \\
\hline 'aalim & knowledge \\
jaami' & pluralistic acceptance \\
jaami' & ethno relativism \\
tawwab, afuww & self-management \\
rahmaan, rahiim, kariim, salaam & peaceful discourse \\
haafidz & proactive involvement \\
haafidz & restoration \\
haafidz & stewardship \\
'aalim & envisioning \\
\hline
\end{tabular}

Thus, religious teaching in this school can be included in the category of positive peace in an effort to eliminate cultural violence at the personal level. 


\section{Conclusion}

This study has found that religious teaching in Syukrillah Islamic Boarding School, Cipongkor, West Java is based on comprehensive religious understanding, recognition of the diversity of opinions in religion, and teaching about the existence of gentle and feminine characteristics (jamaliab) of Allah. The way of teaching religion in this school follows 3 important principles in an effort to avoid the students from radical thinking, namely taraqqi (bottom up), tasamuh (tolerance), and tashawwuf (purfication of soul). This method of teaching is basically in line with the concept of internalizing the values of peace in self, or the third stage in Peace Education. We have also analyzed that the teaching of these feminine names of God corresponds to the five main pillars in Islamic education related to the concept of peace and coexistence, namely attention to common values, disclaim racism, paying attention to minority rights, helping each other in kindness, and justice perspectives in conflict resolution. This research is still a preliminary study and further research is needed, especially by interviewing the santri and making comparisons with other Islamic Boarding School (pesantren) in the region. 


\section{Bibliography}

Afifudin. 2017. Pendekatan Sufistik Dalam Sistem Pendidikan Islam di Perguruan Tinggi: Studi Fenomenologis Program Pencerahan Kalbu di Pesantren Mahasiswa UMI Dar alMukhlisin Labbakkang Pangkep. Inferensi, Vol. 11, No. 1: 7596.

'Arabi, M.I. 1981. Tafsir Al-Qur'an Al-Karim. Beirut: Dar Al-Andalus.

Azra, A. 2005. Jaringan Ulama Timur Tengah dan Kepulauan Nusantara Abad XVII \& XVIII: Melacak Akar-Akar Pembaruan Pemikiran Islam di Indonesia. Jakarta: Kencana.

Badrudin. 2015. Pengantar Ilmu Tasawuf. Serang: Penerbit A-Empat.

Carter, C. (ed). 2010. Conflict Resolution and Peace Education: Transformations across Disciplines. New York: Palgrave MacMillan.

Creswell, John W. 2013. Research Design: Pendekatan Kualitatif, Kuantitatif, dan Mixed. Yogyakarta: Pustaka Pelajar.

Fountain, S. 1999. Peace Education in UNICEF. New York: United Nations Children's Fund Programme Publications.

Galtung, J. 2009. Johan Galtung's view from Europe: Women and Men, Peace and Security. [European Comission Speech Text]. Retrieved from http://www.disappearednews.com/2009/06/ johan-galtungs-view-from-europe-women.html

Galtung, J. 2011. Peace, Positive and Negative. The Encyclopedia of Peace Psychology. Retrieved from https://doi. org/10.1002/9780470672532.wbepp189

Hidayah, R., Andriyani, I.P., Widhanarto, G.P. 2017. Freedom Material in Peace Education Based-Local-Wisdom as Hidden Curriculum. Proceeding of 9th International Conference for Science Educators and Teachers. Vol. 118: 655-657.

Hendry AR., E. 2015. Pengarus Utamaan Pendidikan Damai (Peaceful Education) dalam Pendidikan Agama Islam. At-Turats, Vol. 9, No.1: 3-13. 
Hidayat, A., Sujana, A., Al Gadri, H.H. 2012. Representasi Sosial Komunitas Pesantren Tentang Makna Kedamaian. Inferensi, Vol. 12, No.1: 107-126.

Murata, S. 1996. The Tao of Islam: Kitab Rujukan tentang Relasi Gender dalam Kosmologi dan Teologi Islam. Bandung: Mizan.

Navarro-Castro, L. and Nario-Galace, G. 2010. Peace Education: A Pathway to a Culture of Peace. Quezon City: Center for Peace Education-Miriam College

Nurcholish, A. 2018. Islam dan Pendidikan Perdamaian. Al-Ibrah, Vol. 3, No.2: 140-169.

Page, J. 2010. Peace Education. Paterson, P., Baker, E., and McGaw, B. (eds). International Encyclopedia of Education. (3rd Edition, pp. 850-854). Oxford: Elsevier.

Pilisuk, M. and Nagler, M.N. (eds). 2010. Peace Movements Worldwide. Santa Barbara: ABC-CLIO.

Qaradhawi, Y. 1996. Al-Shahwah Al-Islamiyyah baina Al-Juhud wa Al-Tatharruf. Beirut: Muassasah Al-Risalah.

Ratu, B., Misnah, Amirullah, M. 2019. Peace Education Based On Local Wisdom Nosarara Nosabatutu. Journal of Multicultural Studies in Guidance and Counseling. Vol. 3, No. 2: 106-118.

Rodin, D. 2016. Islam dan Radikalisme: Telaah atas Ayat-ayat "Kekerasan" dalam al-Qur'an. Addin, Vol. 10, No. 1: 29-60.

Setiadi, R. Kartadinata, S. Ilfiandra, Nakaya, A. 2017. A Peace Pedagogy Model for the Development of Peace Culture in An Education Setting. The Open Psychology Journal. Vol. 10: 182-189.

Supriyanto, A. Saputra, W.N.E., Astuti, B. 2019. Peace Guidance and Counseling Based on Indonesian Local Wisdom. Proceedings of the 2019 Abmad Dablan International Conference Series on Education E Learning, Social Science \& Humanities. Vol 370: 177-180.

Syafruddin, D. and Ropi, I. (eds). 2019. Gen Z: Kegalauan Identitas Keagamaan. Jakarta: Pusat Pengkajian Islam dan Masyarakat UIN Syarif Hidayatullah. 
Sukendar. 2011. Pendidikan Damai (Peace Education) Bagi AnakAnak Korban Konflik. Walisongo, Vol. 19, No. 2: 272-286.

Shirazi, Nasir Makarim. 1995. Tafsir-e Nemune, Vol. 2. Tehran: Daar Al-Kitaab Al-Islami.

Syalabi, Al-Syaikh Muhammad Mustafa. 1985. Al-Madkhal fii AlFiqh Al-Islami. 10th edition. Beirut: Al-Daar Al-Jaami'ah.

Subhani, J. 1990. Mabâni-e Hukumat-e Islâmi. Qom: Moassaseh Elmi va Farhanggi Sayyid Al-Shohada.

Subhani, J. 1998. Andisheye Eslami. Qom: Nashr-e Ma'aref.

Syabana, Y. A. 2003. Al-Nizhâm Al-Dauli Al-Jadid Baina Al-Wâqi' Al-Haali wa Al-Tashawwur Al-Islaami. Beirut: Daar Al-Islaam li Al-Thabaa'ah wa Al-Nasyr wa Al-Tauzii' wa Al-Tarjamah.

UNESCO. 2008. UNESCO's work on education for peace and nonviolence: building peace through education. [Document]. Retrieved from https://unesdoc.unesco.org/ark:/48223/ pf0000160787

Qara'ati, M. 1995. Tafsir Noor Vol. 26. Qom: Markaz-e Tahqiqat-e Noor.

Zanjani, A. A. 2000. Fiqh-e Siyaasi Vol. 3. Tehran: Amir Kabir 